How to cite: Sanislai, D., Bătinaş, R., Șerban, Gh. (2020) The Biggest Floods of the 1979-2014 Period and Their Impact on the Population in the Lower Basin of Crasna River (North-West Romania). 2020 "Air and Water Components of the Environment" Conference Proceedings, Cluj-Napoca, Romania, p. 105-116, DOI: 10.24193/AWC2020 10 .

\title{
THE BIGGEST FLOODS OF THE 1979-2014 PERIOD AND THEIR IMPACT ON THE POPULATION IN THE LOWER BASIN OF THE CRASNA RIVER (NORTH-WEST ROMANIA)
}

\author{
Daniel SANISLAI ${ }^{1}$, Răzvan BĂTINAŞ⿻コ一 , Gheorghe ȘERBAN ${ }^{2}$
}

DOI: 10.24193/AWC2020_10

\begin{abstract}
The plain's area, located on the lower course of the Crasna River (the Lower Plain of Someș), during the greatest floods produced in the homonymous basin, suffered from floods exposure, often resulting in immense material damages. Given the fact that the area is subject to frequent flooding, the knowledge of the characteristic elements of the flood waves is of particular importance in the design and placement of buildings, in the design of reservoirs with multiple functions, but especially in the prevention and warning of the population in case of floods. One of the objectives of the study was to quantify the damages caused and to indicate the potential material and human damages, for the administrativeterritorial units affected by the floods, based on the hazard flood map. Along with the risk of floods map, the hazard flood map is part of the documentation for the county territory planning and is detailed in the general, regional and local urban planning plans of the localities. The structural and non-structural measures presented in the study have as a final result the warning of the population, its safety and not lastly the information regarding the measures of prevention and control of these water risk phenomena.
\end{abstract}

Keywords: flood, inundation, defense level, hydrological risk, material damages, psychosocial impact

\section{INTRODUCTION}

In particular, in the last decades, the problem of hydrological hazards and risks and their management has become extremely sensitive, which is why various authors have been concerned with carrying out dedicated theoretical or applied works (Şelărescu and Podani, 1993; Stănescu and Drobot, 2002; Bătinaş, et al., 2002; Sorocovschi, 2017).

The effects of floods can be mitigated, reducing the loss of human life and property damage, by applying two categories of prevention and control measures (Băloiu, 1971; Chiriac et al., 1976; Şelărescu and Podani, 1993; Stănescu and Drobot, 2002; Sorocovschi, 2016; 2017 etc.).

\footnotetext{
1 "Vasile Goldiș" Western University, Faculty of Economics, Computer Science and Engineering, 310414 Arad, Romania, e-mail: sanislaidaniel@yahoo.com

2 "Babeş-Bolyai" University, Faculty of Geography, 400006 Cluj-Napoca, Romania, e-mail: razvan.batinas@ubbcluj.ro gheorghe.serban@geografie.ubbcluj.ro
} 
The structural measures involve the realization of hydrotechnical constructions in the rivers bed and / or in the river catchment. Non-structural measures include flood forecasting, population warning and emergency planning, control of territorial planning and planning of areas prone to flooding, flood protection insurance for affected persons, etc. In the context of non-structural measures, flood forecasting and population warning depend on complex social, economic and environmental conditions (Şelărescu and Podani, 1993; Stănescu and Drobot, 2002; Sorocovschi, 2016; 2017 etc.).

The Crasna River has a length of $134 \mathrm{~km}$ from its source to the border with the Hungarian Republic, of which in the Satu Mare county the length of the watercourse is $63 \mathrm{~km}$ and a catchment area of $1142 \mathrm{~km}^{2}$ out of a total of $2120 \mathrm{~km}^{2}$. The low average altitude of the basin $(237 \mathrm{~m})$ is due to the fact that most of it is developed on two low relief steps, related to the Hills and the Western Plain. This situation is also reflected by the low average slope of the course (3\%), and the shape of the basin, which is elongated on the general north-south direction, while the river network is of dendritic type (Atlas of the Romanian Waters Cadastre, 2002).

The settlements in the lower basin of Crasna have frequently suffered throughout their history as a result of the disasters caused by the floods and inundations developed by the homonymous river at the exit of the hilly area (Fig. 1).

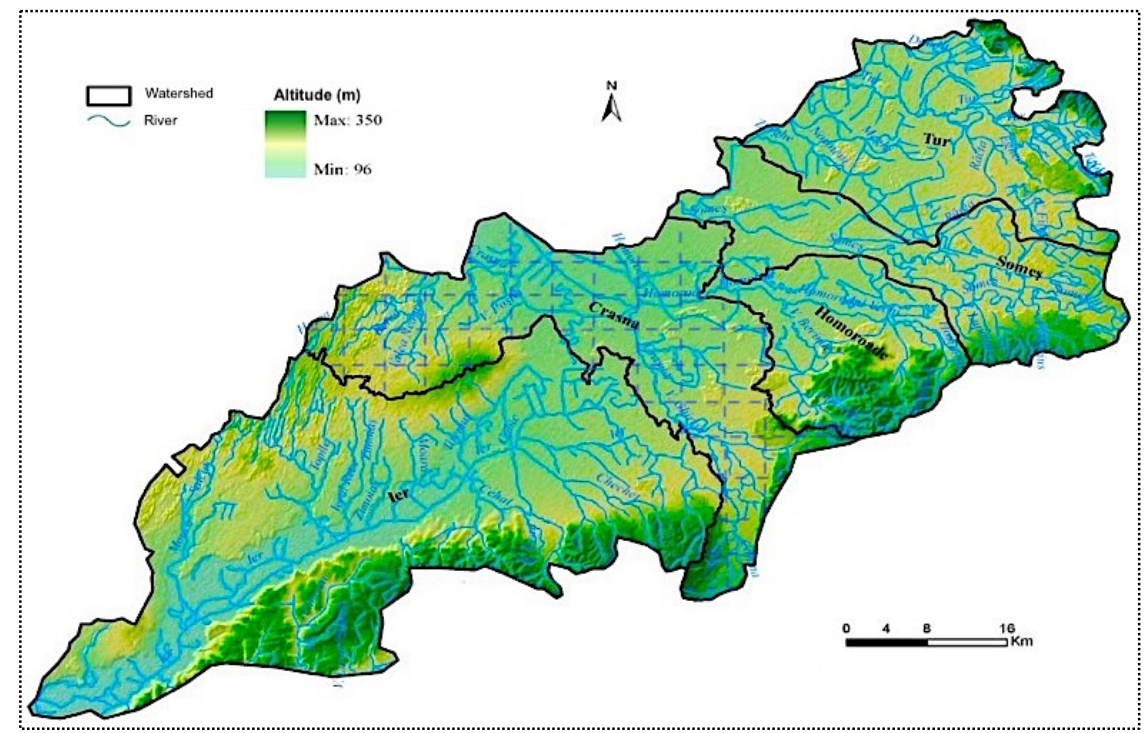

Fig. 1. Lower basin of Crasna River

The risk to the floods is characterized by its nature and probability of occurrence, the degree of exposure of the receivers (the population number and of the goods), the susceptibility to flooding of the receivers and their value, resulting implicitly that in order to reduce the risk it has to be acted on its characteristics (Şelărescu and Podani, 1993; Stănescu and Drobot, 2002; Sorocovschi, 2010; 2016; 2017 etc.).

The essential problem in flood risk management is that of the accepted risk by the population and decision makers, knowing that there is no total protection against 
inundations caused by floods (zero risk), as there is no consensus on the acceptable risk. As a result, acceptable risk must be the result of a balance between the risk and the benefits attributed to an activity as a result of reducing the risk of flooding or government regulation (Risks and Catastrophes Journal, 2002-2019 etc.).

Risk management to floods means the application of policies, procedures and practices aimed at identifying risks, analysing and evaluating them, treating, monitoring and reassessing risks in order to reduce them so that human communities, all citizens, can live, work and satisfy their needs and aspirations in a sustainable physical and social environment (Şelărescu and Podani, 1993; Stănescu and Drobot, 2002; Sorocovschi, 2010; 2016; 2017 etc.).

\section{DATA AND METHODS}

\subsection{Data used}

In order to carry out the study, were consulted data series regarding the maximum flow, in general and the highest floods of the year, in particular (period 1979-2014), from the Satu-Mare and Sălaj Water Management systems, within the Water Basin Administration "Someș-Tisa", with the selection of some cases that left their mark on the lower basin of the Crasna River. Also, studies and internal reports were consulted after the event, from the same institutions, which represented preliminary analyses and, subsequently, detailed on the respective dangerous hydric events, corresponding to the maximum discharge flow. The cartographic materials were elaborated starting from the European Model EU-GeoDEM, 2018 and from the Topographic Map of Romania, 1978-1982 and from some specialized sources online: The National Administration "Romanian Waters", INHGA, etc.

\subsection{Methods}

Common statistical methods and software (like Microsoft Excel 2016) were used in processing the aforementioned information, software dedicated to the processing of data related to floods (like CAVIS), and methods and software for spatialization / attribute data modeling (like ArcGIS 10.4.1), available in the institutions where the authors of this study are active.

The analysis method was applied throughout all the work stages, taking into account the specificity and complexity of the data submitted to the study, as well as the natural and anthropic particularities of the study area.

\section{RESULTS}

\subsection{Floods frequency on Crasna River between 1979-2014 period}

The periods of maximum flow are an important phase in the rivers' flow regime, both by their extreme character and by the effects they can have on the components of the environment. 
The phenomena from the high flow periods usually occur in the form of impulses with varying intensities, dimensions and durations, which in the water regime of the rivers are manifested in the form of large discharges and floods. Knowing the genesis and mechanisms of production of these phenomena offers the possibility of preventing and combating the economic, social and ecological effects that they can cause (Sorocovschi, 2010; 2016; 2017; Pandi, 2010; 2011; Bătinaș and Sanislai, 2012; Sanislai and Bătinaș, 2012, etc.).

The monthly and seasonal frequency of the floods, especially of the high intensity ones, is particularly important in the activity of efficient management of water resources. The analysis of the periods in which there were recorded floods on the Crasna River was done taking into account the value of the peak flow, admitting two characteristic types:

- normal floods, those included in the "biggest floods of the year" data sheet;

- important floods, with the peak flow greater than or equal to the maximum multiannual average flow.

For the calculus of this parameter, data were collected regarding the periods of manifestation of the floods from two hydrometric stations along the Crasna River, one located upstream of Domănești, in Supur, and the other, near the locality of Domănești.

In order to have a common calculation period, to allow comparison of the obtained results, a unitary interval was chosen for the two stations, 35 years (19792014). The study period can be considered sufficiently long and also representative, with a significant variation of the absolute maximum flows recorded at the two stations (Table 1).

Table 1. Seasonally frequency of floods in the hydrographic basin of Crasna River on the territory of Someșului Plain

\begin{tabular}{|l|l|c|c|c|c|c|c|}
\hline \multirow{2}{*}{ River } & \multirow{2}{*}{ Station } & \multirow{2}{*}{$\begin{array}{c}\text { Hmed } \\
(\mathbf{m})\end{array}$} & \multirow{2}{*}{$\begin{array}{c}\text { F } \\
\left.\mathbf{( k m}^{\mathbf{2}}\right)\end{array}$} & \multicolumn{4}{|c|}{ Season } \\
\cline { 5 - 8 } & & 310 & 1170 & 32.6 & $\mathbf{3 6 . 6}$ & 19.3 & 11.5 \\
\hline Crasna & Supuru de Jos & & & & \\
\hline Crasna & Domănești & 261 & 1705 & 32.7 & $\mathbf{3 8 . 5}$ & 21.1 & 7.6 \\
\hline
\end{tabular}

Regarding the frequency of floods during seasons, it is noted that, in the hydrographic basin of Crasna, the maximum occurrence of floods is in Spring (36$46 \%$ ) recorded at the stations of Domăneşti and Supuru de Jos (Fig. 2).

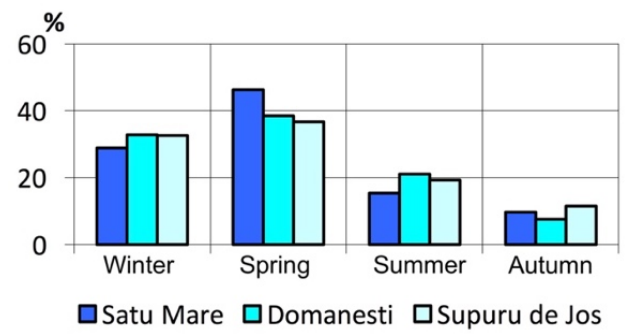

Fig. 2. Comparison of seasonal frequency of floods on Crasna and Someș River (1979 - 2014). 
The monthly frequency of the floods shows a maximum in June on Crasna in Domăneşti (17.3\% of the total number of selected floods) and in April on Someş in Satu Mare (23.1\%).

During 1979 - 2014 period, we can observe differences in the monthly frequency of the floods at the two hydrometric stations, which led to the division into two groups. Thus, the first group includes the Supuru de Jos station with high frequencies in the Winter and Spring months, while the second group is represented by Domănești station with a maximum frequency recorded in early summer, respectively June (Table 2).

Table 2. Monthly frequency of floods during 1979 - 2014 (in \%, of all cases)

\begin{tabular}{|l|c|c|c|c|c|c|c|c|c|c|c|c|c|}
\hline \multirow{2}{*}{ River } & \multirow{2}{*}{ Station } & \multicolumn{10}{|c|}{ Month } \\
\cline { 3 - 13 } & & I & II & III & IV & V & VI & VII & VIII & IX & X & XI & XII \\
\hline Crasna & Supuru de Jos & 11.5 & $\mathbf{1 7 . 3}$ & 15.4 & 13.5 & 7.7 & 13.5 & 5.8 & - & 1.9 & 3.8 & 5.8 & 3.8 \\
\hline Crasna & Domănești & 15.4 & 13.5 & 11.5 & 13.5 & 13.5 & $\mathbf{1 7 . 3}$ & 3.8 & - & 1.9 & 3.8 & 1.9 & 3.8 \\
\hline
\end{tabular}

\subsection{Flood parameters and their report against the defense levels}

The parameters of each flood were taken into account, processing the values in a global synthesis that included the maximum flows and levels, as well as the other data related to the duration, the drained water volumes, the time interval in which the defense levels were exceeded. at the hydrometric stations, the drainage coefficients, the specific maximum flow rates, all in order to highlight the exposure of the population to the risk of flooding.

Taking into account the data from the two stations with a continuous range of values from the establishment until 2014, the following results of the mentioned parameters were obtained (Table 3).

Table 3. Data on the parameters of the first two higher floods at the hydrometric stations in the lower basin of Crasna River

\begin{tabular}{|c|c|c|c|c|c|c|c|c|c|c|c|c|}
\hline \multirow{2}{*}{ Station } & \multirow{2}{*}{ Ye. } & \multirow[b]{2}{*}{ Mo. } & \multicolumn{3}{|c|}{ Volume (mil. $\mathbf{m}^{3}$ ) } & \multicolumn{3}{|c|}{ Duration (hours) } & \multirow{2}{*}{$\begin{array}{l}\text { Base } \\
\text { disch. } \\
\left(\mathrm{m}^{3} / \mathrm{s}\right)\end{array}$} & \multirow{2}{*}{$\begin{array}{c}\text { Max. specific } \\
\text { discharge } \\
\left(1 / \mathbf{s}^{*} \mathbf{k m}^{2}\right)\end{array}$} & \multirow{2}{*}{$\begin{array}{c}\text { Drained } \\
\text { layer } \\
(\mathrm{mm})\end{array}$} & \multirow[b]{2}{*}{$\gamma$} \\
\hline & & & total & base & precip. & total & inc. & dec. & & & & \\
\hline \multirow{2}{*}{ Domănești } & 1970 & $\mathrm{~V}$ & 109,01 & 25,18 & 83,84 & 428 & 66 & 362 & 16,34 & 161,9 & 49,2 & 0,26 \\
\hline & 2000 & IV & 44,2 & 12,21 & 31,99 & 216 & 54 & 162 & 15,7 & 78 & 18,8 & 0,43 \\
\hline \multirow{2}{*}{$\begin{array}{c}\text { Supuru de } \\
\text { Jos }\end{array}$} & 2014 & III & 29,3 & 13,64 & 23,54 & 93 & 22 & 71 & 31,22 & 196,4 & 21,3 & 0,8 \\
\hline & 2000 & IV & 22,5 & 5,82 & 16,82 & 84 & 21 & 63 & 19,25 & 161,5 & 14,4 & 0,4 \\
\hline
\end{tabular}

The hydrographs of the two largest floods from the analyzed stations are shown in the figures below, respectively the floods recorded at the Domănești hydrometric station (top) and at the Supuru de Jos hydrometric station respectively (Fig. 3).

For a more complete synthesis of the impact of these risk phenomena in the river basin of Crasna on the locality of Domănești, we have considered the most important floods that took place at the level of the two stations, underlining the maximum flow and level, respectively the date of reaching these extreme values. (Table 4). 

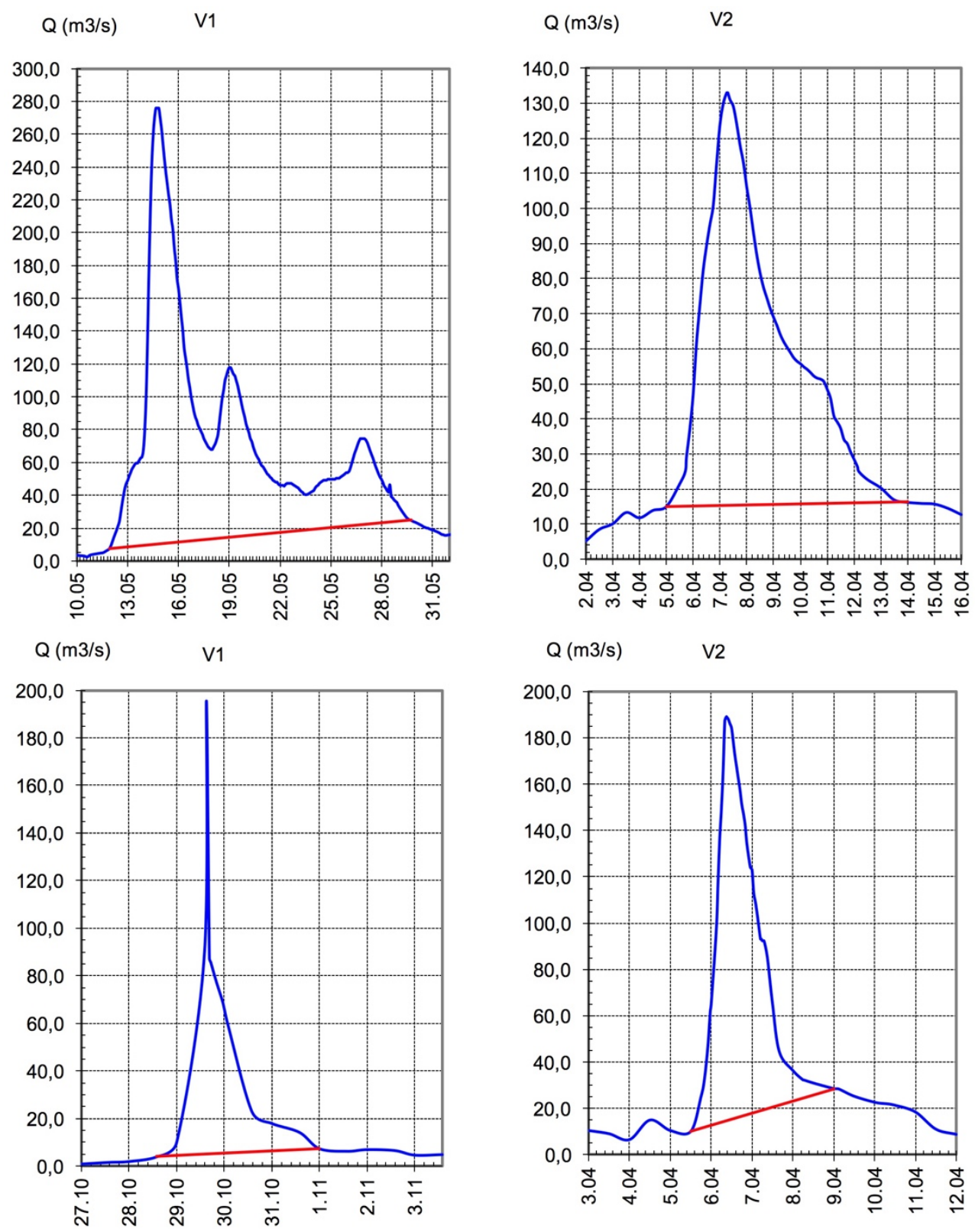

Fig. 3. The hydrographs of the two largest floods

A particular aspect of the assessment of the risks that these water phenomena induce is related to the report of the values reached at the defence levels established on the watercourses at the hydrometric stations. The defense levels associated with the water courses in the perimeter of the study area are presented below (Table 5). 
Table 4. The largest floods in the studied area recorded at hydrometric stations

\begin{tabular}{|c|c|c|c|c|c|}
\hline River & Station & Q max. & H max. & Year & Day \\
\hline \multirow{4}{*}{ Crasna } & \multirow{3}{*}{ Domănești } & 342 & 701 & 1970 & 12.06 \\
\cline { 3 - 6 } & & 288 & 703 & 1974 & 14.06 \\
\cline { 3 - 6 } & & 276 & 671 & 1970 & 14.05 \\
\cline { 3 - 6 } & \multirow{3}{*}{ Supuru de Jos } & 275 & 590 & 1970 & 11.06 \\
\cline { 3 - 6 } & & 244 & 638 & 1989 & 8.05 \\
\cline { 3 - 6 } & & 167 & 564 & 1988 & 17.03 \\
\hline
\end{tabular}

The incidence of exceeding the defense levels in the case of the floods carried out in the study area, in which the data fund allowed us a thorough evaluation, led to the delimitation of the time intervals during which the defense levels were exceeded, during the floods, respectively the duration in hours, during which these critical thresholds were covered by the water level.

Table 5. Defense levels of Crasna River within its basin (S.G.A. Satu Mare)

\begin{tabular}{|c|c|c|c|c|c|c|c|c|}
\hline Stream & Station & C.P.A. & C.A. & C.I. & C.P. & F I & F II & F III \\
\hline \multirow{4}{*}{ Crasna } & Supur & 250 & 300 & 400 & 500 & 300 & 400 & 500 \\
\cline { 2 - 8 } & Acâș & & & & & & & \\
\cline { 2 - 8 } & Craidorolț & & 350 & 450 & 550 & 350 & 450 & 550 \\
\cline { 2 - 8 } & Ghilvaci & & 250 & 330 & 450 & 270 & 350 & 420 \\
\cline { 2 - 8 } & Domănești & & 400 & 500 & 550 & 400 & 500 & 550 \\
\cline { 2 - 8 } & Berveni & & 490 & 590 & 700 & 500 & 590 & 650 \\
\hline
\end{tabular}

C.P.A. - pre-warning defense level, C.A. - warning level, C.I. - inundation level, C.P. danger level, F I, F II, F III - defense levels corresponding to dykes' area.

\section{DISCUSSIONS}

\subsection{Impact of floods on settlements in the lower basin of the Crasna River}

Vulnerability is the susceptibility of objects to be affected by hazards. As a result of the destructive effects of a hazard, people's lives and health are at direct risk. They are at risk as a result of the destruction of buildings, harvests, livestock or equipment, income of the population and its means. Each type of hazard puts at risk a number of elements (O.U.G. no. 21 from 04/15/2004).

Many disaster mitigation actions are aimed at reducing vulnerability. In order to reduce the vulnerability, those in charge of development planning must understand which of the risk recipients are the most exposed based on the main hazards identified, in this case, those of floods and inundations (Sorocovschi, 2016; 2017; Risks and Catastrophes Journal, 2002-2019 etc.).

The vulnerability can be characterized by two categories of aspects: tangible and intangible. For example, in the case of floods, the tangible aspects include whatever is located in the flood zone: people, buildings, harvests, livelihoods, machinery and equipment, infrastructure facilities, etc., all with a major psychological impact both in the incipient phase and in the developing stage of risk phenomenon and more important, the consequences of these hazards. As intangible aspects are considered 
social cohesion, community structure, cultural - artistic cohesion (Order 638/2005 of the M.A.I. and Order 420/2005 of the M.M.G.A.).

The water phenomena that are manifested by the passage of important volumes of water at the level of the river Crasna have generated damages on the network infrastructure (roadways and rail), occupying agricultural lands with a consistent volume of water, stagnant for a longer period of time and damages to the habitat infrastructure (housing, public and social establishments). Indirect damages are expressed through discontinuities in the normal program of various activities (population supply, freight and persons transport). The evaluation of the characteristics and effects generated by the damages associated with the floods were analyzed sequentially, chronologically, according to the availability of the accessed data and the typology of the recorded damages. In this regard, the most significant water events that took place in the study area were taken into account. The most significant floods and inundations developed in the analyzed perimeter generated important damages that were often manifested by affecting social-economic objectives, flooding agricultural lands, compromising hydrotechnical works which usually defend the banks and riverbeds, against erosion processes.

For example, in 1996, the most relevant water risk phenomenon took place between October 19-25, when the watercourse of Crasna was affected by the flood especially in the middle and downstream sector, deteriorating shore works, on a length of $100 \mathrm{~m}$, around Craidorolţ locality and also about 350 ha of hay were flooded.

In 1998, the most important surplus water event that caused material damage, was generated between June 15 - July 22, when large floods have been produced by torrential rains, storms, associated with hail. This event was affecting many localities on the course of Crasna, respectively Berveni (140 ml protection dam; 479 ha arable land; 140 ha pasture), Căpleni (520 $\mathrm{ml}$ protection dam), Moftin (500 $\mathrm{ml}$ protection dam ; 5000 ha of arable land; 400 ha of pasture; 21 houses and annexes), Terebești (2670 ha of arable land; 1 ha of vineyard), Craidorolt (1195 ml of protection dams; 1738 ha of arable land; 125 ha of pasture; 1 house), Beltiug ( $300 \mathrm{ml}$ protection dam; $90 \mathrm{ml}$ dam erosion), Acâș (470 $\mathrm{ml}$ protection dam), Supur $(400 \mathrm{ml}$ protection dam; $1575 \mathrm{ml}$ shore erosion; $0.4 \mathrm{~km}$ communal road; 1760 ha arable train; 53 flooded households).

In 2000, surplus water events were reported, which led to significant damage to the territorial infrastructure. The most important from this point of view were the floods that occurred between March and April. The balance of the damages produced at the level of the study area is presented as follows (Table 6).

In 2004, the flood with the most significant effects was carried out between 25 and 29 of March. The phenomenon was determined by a strong rainfall which led to cumulative values exceeding threshold values above $501 / \mathrm{sqm}$. As a result, the flood reached the critical thresholds at Domăneşti station.

In 2006, between March 4 and April 27, some flood with rain-snow melting genesis type occurred, which generated increases in the water level at the hydrometric stations on Crasna (Supur - exceeding the inundation level, Craidorolţ - exceeding the danger level, Domăneşti - exceeding the danger level). Another small-scale flood affected the lower sector of Crasna between April 7 and April 12, 
with discharge values over the warning level. A third episode was recorded between April 12 and 27, with the exceeding of warning and inundation values at Supur, Craidorolţ and Domăneşti stations.

Table 6. Damage caused during the floods from 24.03 - 07.04.2000 in Crasna basin

\begin{tabular}{|c|l|l|}
\hline No. & $\begin{array}{c}\text { Affected } \\
\text { locality }\end{array}$ & \multicolumn{1}{c|}{ Damages } \\
\hline 1. & Supur & 60 households; 72 house annexes $; 40 \mathrm{ml}$ protective dam \\
\hline 2. & Dobra & 6 households and house annexes \\
\hline 3. & Giorocuţa & 21 households and 15 house annexes \\
\hline 4. & Socond & 9 households \\
\hline 5. & Craidorolt & $1100 \mathrm{ml}$ shore erosion and protective dam \\
\hline 6. & Terebeşti & $220 \mathrm{ml}$ dykes \\
\hline 7. & Moftin & $670 \mathrm{ml}$ slippery slopes from protective dams \\
\hline 8. & Căpleni & $3680 \mathrm{ml}$ protective dams \\
\hline 9. & Berveni & $320 \mathrm{ml}$ protective dams \\
\hline
\end{tabular}

As a result of the floods on the Crasna River, several shore-works have been affected. Thus, at the non-permanent accumulation Moftin the water entered the compartment II by pouring over the compartmentation dam, thus on 05.03 at 22 o'clock on a length of $120 \mathrm{~m}$ and at 24 o'clock on a length of $200 \mathrm{~m}$. On 06.03 at o'clock 06 the compartmentation dam was washed-away up to its the base on a length of $27 \mathrm{~m}$. On 10.03 due to the internal waters accumulated in the protected area on the left bank of Crasna River in the area of Lucăceni village - Berveni commune were flooded 3 households.

Between May 29 and July 4, there were two flood events that caused significant damage, especially in the basin of Crasna and its tributaries. The first flood took place between May 31 - June 13, generating discharge values that exceeded the defense levels at the hydrometric stations Supur, Craidorolţ and Domăneşti.

In 2007, the most significant water events with effects in the territory took place between February 7 - March 5, being determined by the significant amounts of rainfall in the river basin of Crasna, but also of snow melts. from the upper basin of the mentioned river. Thus, the critical values of the defense levels were exceeded, as follows: the flood from $23.02-24.02$, with the exceeding of the warning level in Domăneşti, and the flood from 03.03 - 05.03, also exceeding the warning level.

In 2008, there were two major floods with effects in the territory. The genesis of the floods has evolved from the significant amounts of rainfall accumulated in the catchment area. Thus, a first flood occurred between 18 and 22 June 2006, when the rainfall amount was exceeded $451 / \mathrm{m}^{2}$. This excess of water was the cause of the exceeding critical defense thresholds at the hydrometric stations: Domăneşti, Craidorolţ and Berveni on Crasna.

As a result, the levels reached on the watercourses, monitored by hydrometric stations, reached and exceeded the warning and inundation levels in Supuru de Jos, on Crasna. Further down, the maximum historical levels were reached in Craidorolt $(\mathrm{H}=604 \mathrm{~cm})$, respectively Domăneşti $(592 \mathrm{~cm})$, values that exceeded the danger 
level. High values were reached also on the tributaries: the Maja valley at Corund, where it reached a historical maximum level of $476 \mathrm{~cm}$, while on the Maria valley at Răteşti, the threshold for the inundation level was exceeded.

As a result of these phenomena, the effects in the territory were materialized by significant damages, which compromised in certain situations the resistance of the buildings, the crops, the road access infrastructure, and their value reaching RON $2,465,200$.

\subsection{Floods and hydrological warnings in the lower basin of Crasna River}

The hydrological warning is issued when the possibility of exceeding the defense levels or the possibility of producing other dangerous hydraulic phenomena (important flows on the slopes, torrents, non-permanent valleys) is provided based on the weather forecasts. The hydrological alert is issued when it is foreseen the imminent overrun of the defense levels and / or the production of other dangerous hydrological phenomena (important flow on the slopes, torrents, non-permanent river valleys) based on the weather forecasts and the state of the rivers (Order 823 / MMGA and 1427 / MAI).

The anticipation time is at least 24 hours for watercourses that react quickly to fallen rainfall and at least 2-3 days for watercourses that react more slowly to fallen rainfall or for the propagation of floods formed in the upper areas of the river basin.

From the analysis of the situation at the level of the study period, for Domănești, the unfolded phenomena showed high frequencies of issuing the yellow code, which implies the exceeding of warning level at the hydrometric stations. (Figure 5).

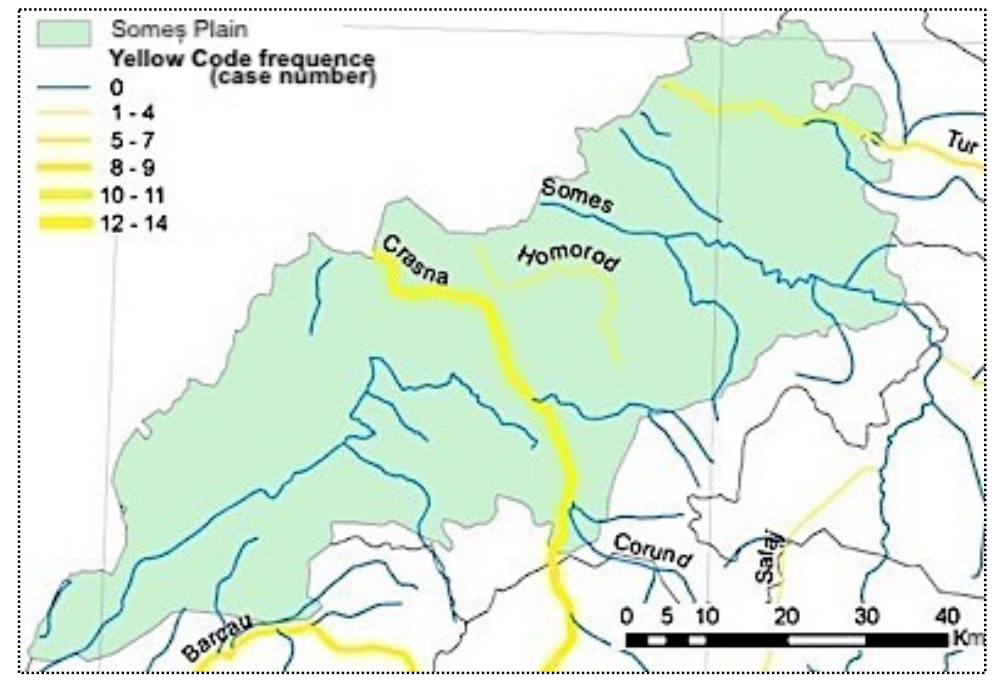

Fig. 5. The frequency of issuing the yellow code on the rivers in the Someş Plain.

Thus, it was observed that the most exposed watercourse, of the entire Plain of Someș, is Crasna, with a number of 14 cases, directly affecting the population of Domănești village. 


\section{CONCLUSIONS}

The analysis of the risk hydric phenomena represent, with certainty, a major current problem of the human society, and the understanding of their appearance and manifestation, at the level of the causes and the effects, requires a complex and increasingly sustained approach, as a result the interest and the concern are noted increasingly acute of the researchers and the ecological and social dimension of these phenomena. The impact they have, the vulnerability of the exposed elements, are becoming nevertheless the subject of some university lectures. In this sense, we have considered important, the analysis of the floods, by approaching their evolution, definition and characterization as a water risk phenomenon, together with the presentation of the main prevention and control measures that this phenomenon implies.

Knowing the genesis and mechanisms of production of these phenomena offers the possibility of preventing and combating the economic, social and ecological effects that they can cause. The anthropic component constitutes the most dynamic factor of the geographical landscape but at the same time the most vulnerable part in the face of extreme geographical phenomena, suffering losses of human lives.

In order to prevent and combat the effects generated by extreme events in the researched region, the priority must be given to raising public opinion regarding the correct perception of floods and their responsibilities at the individual level, of the community and local administration. The harmonious integration of the community in the environment can be done only on the basis of an appropriate educational process in which several responsible factors must participate.

\section{ACKNOWLEDGEMENTS}

We thank the "Someș-Tisa" Water Basin Administration - Satu Mare and Sălaj Water Management Systems, for the technical and informational support provided and for the Babeș-Bolyai University for the software support and the PC technique made available for information processing and spatial analysis.

\section{REFERENCES}

1. Băloiu, V. (1971), Gospodărirea apelor, Edit. Didactică şi Pedagogică, București.

2. Bătinaș R., Sanislai D., (2012), Some aspects regarding the flood waves analysis at Satu Mare Hydrometric Station on the Someș River. Conferința anuală: "Aerul și Apa, componente ale mediului", Universitatea "Babeș-Bolyai", Facultatea de Geografie, Cluj Napoca, 23-24 Martie 2012, Cluj Napoca;

3. Bătinaş, R., Sorocovschi, V., Șerban, Gh., (2002), Fenomene hidrologice de risc induse de viituri in bazinul inferior al Arieşului, Seminarul Geografic Dimitrie Cantemir, Iaşi.

4. Chiriac V., Filotti A., Teodorescu I. (1976), Lacuri de acumulare. Edit. Ceres, Bucureşti. 
5. Pandi, G. (2010), Undele de viitură şi riscurile induse, în "Riscuri şi catastrofe", Vol. 8, Nr. 2, Editor Victor Sorocovschi, Edit. Casa Cărţii de Știință, pp. 55-66

6. Pandi, G. (2011), The influenced flow regimes, 2011 "Air and Water - Components of the Environment" Conference Proceedings, Cluj-Napoca, Romania, p. 38-44

7. Sanislai D., Bătinaș R., (2012), Some aspects regarding the flash flood analysis and the natural flood risk map of Someș Plain. Revista "Riscuri și Catastrofe". Centrul de Cercetare a Hazardelor și Riscurilor Geografice. Universitatea "Babeș-Bolyai" , Facultatea de Geografie, Cluj Napoca;

8. Şelărescu M., Podani M. (1993), Apărarea impotriva inundaţiilor, Edit. Ştiinţifică, Bucureşti

9. Sorocovschi. V. (2010), Hidrologia uscatului, Edit. Casa Cărţii de Ştiinţă, Cluj-Napoca.

10. Sorocovschi. V. (2016), Riscurile naturale. Aspecte teoretice și aplicative., Edit. Casa Cărţii de Ştiinţă, Cluj-Napoca.

11. Sorocovschi. V. (2017), Fenomene şi procese hidrice de risc. Partea I - Domeniul continental, Edit. Casa Cărţii de Ştiinţă, Cluj-Napoca.

12. Stănescu, V. Al., Drobot, R. (2002), Măsuri nestructurale de gestiune a inundaţiilor, Edit. $\mathrm{H}^{*} \mathrm{G}^{*} \mathrm{~A} *$, Bucureşti

13. *** (1978-1982), Topographic Map of Romania (in Romanian), 1:25000. Military Topographic Direction, Bucharest.

14.*** (1992) The Atlas of Water Cadastre of Romania (in Romanian), Ministry of Environment and Aquaproject S.A., Bucureşti, 683 p.

15.*** (2002-2019), Risks and Catastrophes Journal, Edit. Sorocovschi, V., Edit. Casa Cărții de Știință, Cluj-Napoca.

16. *** (2004), Ordonanţa de urgenţă privind Sistemul Naţional de Management al Situaţiilor de Urgenţă, O.U.G. nr. 21/2004 din 15/04/2004, Monitorul Oficial, Partea I nr. 361 din 26 aprilie 2004.

17. *** (2005), Regulamentul privind gestionarea situaţiilor de urgenţă generate de inundaţii, fenomene meteorologice periculoase, accidente la construcţii hidrotehnice şi poluări accidentale, Ordin 638/2005 al Ministerului Administraţiei şi Internelor, respectiv 420/2005 al Ministerului Mediului şi Gospodăririi Apelor, Monitorul Oficial 455 din 30 mai 2005.

18.*** (2018), Copernicus Land Monitoring Service - EU-DEM, https://www.eea.europa.eu/data-and-maps/data/copernicus-land-monitoring-service-eudem.

19. *** Records of S.T.W.B.A. ("Someș-Tisa" Water Basin Administration - Satu Mare Water Management System and Sălaj Water Management System, in Romanian) 